\title{
MINUMAN JAHE HANGAT UNTUK MENGURANGI EMESIS GRAVIDARUM PADA IBU HAMIL DI PUSKESMAS NALUMSARI JEPARA
}

\author{
Dyah Ayu Wulandari ${ }^{1}$, Dwi Kustriyanti ${ }^{2}$, Rofiatul Aisyah ${ }^{3}$ \\ STIKes Karya Husada Semarang \\ Jl. Kompol R. Soekanto No. 46 Semarang- 081325132192 \\ tata.talitha@gmail.com
}

\begin{abstract}
ABSTRAK
Emesis gravidarum merupakan mual muntah yang terjadi selama kehamilan. Mual terjadi pada pagi hari, tetapi ada yang timbul malam hari. Data di Jawa Tengah keluhan mual muntah pada ibu hamil mencapai $40-60 \%$ dari total kehamilan. Rasa mual pada awal kehamilan dapat dikurangi dengan menggunakan terapi komplementer antara lain dengan memberikan minuman jahe hangat. Pemberian minuman jahe efektif dalam mengatasi mual muntah ibu hamil trimester I. Keunggulan jahe adalah kandungan minyak atsiri yang mempunyai efek menyegarkan dan memblokir reflek muntah, sedang gingerol dapat melancarkan darah dan saraf bekerja dengan baik.. Penelitian ini bertujuan untuk mengetahui pengaruh pemberian minuman jahe hangat terhadap emesis gravidarum pada ibu hamil trimester I di Puskesmas Nalumsari Jepara. Metode : Quasy Eksperiment dengan pendekatan Control Group Pre-Posttest Design. Populasi penelitian ini adalah ibu hamil di Puskesmas Nalumsari Jepara. Teknik pengambilan sampel menggunakan teknik Purposive Sampling sehingga besar sampel adalah 50 responden. Uji analisis data menggunakan uji Wilcoxon dan Mann Whitney. Hasil : Uji Mann Whitney mendapatkan nilai p 0.000. Kesimpulan : Terdapat pengaruh pemberian minuman jahe hangat terhadap emesis gravidarum pada ibu hamil trimester I di Puskesmas Nalumsari Jepara.
\end{abstract}

Kata Kunci: jahe; emesis gravidarum

\begin{abstract}
Emesis gravidarum is nausea and vomiting that occurs during pregnancy. Nausea occurs in the morning, but there are those that occur at night. Data in Central Java complaining of nausea and vomiting in pregnant women reaches $40-60 \%$ of total pregnancies. Nausea in early pregnancy can be reduced by using complementary therapies, among others, by giving warm ginger drinks. Ginger drink is effective in dealing with nausea and vomiting for pregnant women in the first trimester. The advantage of ginger is the content of essential oils that have a refreshing effect and block the vomiting reflex, while gingerol can launch blood and nerves work well. This study was to determine the effect of ginger drinks toward emesis gravidarum at pregnancy first trimester in Puskesmas Nalumsari Jepara. The method of this study used Quasy Experiment with the Control Group Pre-Posttest Design. The population were mother in first trimester of pregnancy in Puskesmas Nalumsari Jepara. The sampling technique used Purposive Sampling so the size samples were 50 peoples. The data analize used Wilcoxon and Mann Whitney test. Result: The Wicoxon test got value of $p 0.000$, Mann Whitney test got value of $p$ 0.000. Conclusion: There was an effect of ginger drink toward emesis gravidarum at pregnancy first trimester in Puskesmas Nalumsari Jepara.
\end{abstract}

Keywords: ginger; emesis gravidarum 


\section{LATAR BELAKANG}

Keluhan mual muntah pada emesis gravidarum merupakan hal yang fisiologis, akan tetapi apabila keluhan ini tidak segera diatasi maka akan menjadi hal yang patologis Mual dan muntah juga menyebabkan cairan tubuh berkurang dan terjadi hemokonsentrasi yang dapat memperlambat peredaran darah sehingga mempengaruhi tumbuh kembang janin. Di Indonesia sebanyak 50\%-75\% ibu hamil mengalami mual dan muntah pada trimester pertama atau awal-awal kehamilan. Data di Jawa Tengah keluhan mual muntah pada ibu hamil mencapai $40-60 \%$ dari total kehamilan (Kemenkes RI, 2017). Upaya untuk mengurangi frekuensi muntah dapat diberikan beberapa tindakan seperti obat, selain obat, rasa mual pada awal kehamilan dapat dikurangi dengan menggunakan terapi komplementer antara lain dengan tanaman herbal atau tradisional yang bisa dilakukan dan mudah didapatkan seperti jahe, daun peppermint, lemon dan lain sebagainya (Parwitasari, 2015). Ibu hamil yang mengalami mual muntah terjadi penurunan setelah diberikan minuman jahe (Putri, 2017). Keunggulan jahe adalah kandungan minyak atsiri yang mempunyai efek menyegarkan dan memblokir reflek muntah, sedang gingerol dapat melancarkan darah dan saraf bekerja dengan baik. Aroma harum jahe dihasilkan oleh minyak atsiri, sedang oleoresin menyebabkan rasa pedas yang menghangatkan tubuh (Khasanah, 2017). Pemberian minuman jahe efektif dalam mengatasi morning sickness (Rofiah, 2017). Ibu yang mengkonsumsi jahe hangat merasakan mual muntah berkurang dan ibu yang menghisap aroma lemon melaporkan keluhan mual muntah masih sering dialami.

Survey yang dilakukan penulis kepada 10 ibu hamil yang mengalami mual muntah didapatkan rata-rata mual muntah setiap hari berkisar 6-10 kali dalam sehari. Keluhan tersebut membuat tidak nyaman serta membuat tubuh menjadi lemah. Upaya untuk mengurangi rasa mual muntah dengan cara menghindari bau yang menyengat, minum air hangat, makan permen, istirahat, memakai masker serta upaya fasilitas kesehatan untuk mengatasi mual muntah pada ibu hamil dengan memberikan vitamin piridoksin (B6) dan antasida.

Atas dasar ini penulis termotivasi untuk melakukan penelitian dengan judul pengaruh pemberian minuman jahe terhadap emesis gravidarum pada ibu hamil trimester I di Puskesmas Nalumsari Jepara.

Penelitian ini bertujuan untuk menganalisis pengaruh pemberian minuman jahe terhadap emesis gravidarum pada ibu hamil trimester I di Puskesmas Nalumsari Jepara.

\section{METODE}

Berdasarkan permasalahan dan tujuan penelitian, jenis penelitian ini adalah Quasi Experimen. Rancangan penelitian yang digunakan adalah Non Equivalent Control Group Design. Sampel dalam penelitian ini adalah ibu hamil trimester I yang mengalami emesis gravidarum di wilayah Kerja Puskesmas Nalumsari Jepara data 3 bulan terakhir (Juni-Agustus 2018) adalah 50 responden dengan pembagian 25 untuk intervensi dan 25 untuk kontrol. Teknik pengambilan sampel menggunakan teknik Purposive Sampling.

Teknik pengumpulan data: Pada kelompok intervensi, tindakan pemberian minuman jahe hangat diulang selama 14 kali dalam 7 hari sehingga setiap hari 2 kali. Pada kelompok kontrol, tindakan pemberian inhalasi lemon diulang selama 14 kali dalam 7 hari sehingga setiap hari 2 kali.

Penentuan analisa data dilakukan uji normalitas data dengan uji Shapiro Wilk. Hasil uji normalitas pada pada pemberian miuman jahe pada pretest mendapatkan nilai p 0.128, sedangkan pada posttest mendapatkan nilai $p$ 0.140. Hasil ini menunjukkan bahwa data berdistribusi normal sehingga analisa data menggunakan uji Paired Samples T-test. Analisa perbedaan efektivitas antara kelompok minuman jahe dan kelompok lemon menggunakan uji Mann Whitney karena distribusi data selisih antara sebelum dan sesudah tidak normal yaitu $p$ value 0.000 . 
HASIL

Tabel 1 Pengaruh Pemberian Minuman Jahe Hangat terhadap Emesis gravidarum

\begin{tabular}{cccc}
\hline $\begin{array}{c}\text { Emesis } \\
\text { Gravidarum }\end{array}$ & Men士SD & Min-Max & $\begin{array}{c}\mathbf{p} \\
\text { value }\end{array}$ \\
\cline { 1 - 2 } Sebelum & $13.0 \pm 81.441$ & $10-17$ & \multirow{2}{*}{0.000} \\
\cline { 1 - 2 } Sesudah & $7.56 \pm 1.502$ & $5-10$ & \\
\hline
\end{tabular}

Berdasarkan Tabel 1 diketahui bahwa frekuensi mual muntah pada kelompok intervensi sebelum tindakan rata-rata skor 13.08, sedangkan setelah tindakan mendapatkan rata-rata skor 7.56. Hasil uji analisa Paired Samples $T$ test (data berdistribusi normal) mendapatkan nilai $p 0.000$ yang menunjukkan bahwa pemberian minuman jahe efektif terhadap frekuensi emesis gravidarum pada ibu hamil trimester I di Puskesmas Nalumsari Jepara.

Tabel 2 Pengaruh Pemberian Inhalasi Lemon terhadap Emesis gravidarum

\begin{tabular}{cccc}
\hline $\begin{array}{c}\text { Emesis } \\
\text { Gravidarum }\end{array}$ & Mean+SD & Min-Max & $\begin{array}{c}\mathbf{p} \\
\text { value }\end{array}$ \\
\cline { 1 - 3 } Sebelum & $13.96 \pm 1.020$ & $12-15$ & \multirow{2}{*}{0.000} \\
\cline { 1 - 2 } Sesudah & $12.88 \pm 1.166$ & $11-15$ & \\
\hline
\end{tabular}

Berdasarkan Tabel 2 diketahui bahwa frekuensi mual muntah pada kelompok kontrol sebelum tindakan rata-rata adalah 13.9 dan setelah tindakan rata-rata adalah 12.8. Hasil analisa data Wilcoxon mendapatkan nilai $p$ 0.000 yang menunjukkan bahwa lemon efektif terhadap frekuensi emesis gravidarum pada kelompok kontrol ibu hamil trimester I di Puskesmas Nalumsari Jepara.

Table 3 Efektivitas Jahe terhadap Emesis Gravidarum

\begin{tabular}{ccc}
\hline Emesis Gravidarum & Mean Rank & p value \\
\cline { 1 - 2 } Pemberian Jahe & 37.74 & \multirow{2}{*}{0.000} \\
\cline { 1 - 2 } Pemberian Lemon & 13.26 & \\
\hline
\end{tabular}

Hasil analisa Mann Whitney untuk mencari perbedaan rata-rata antara kelompok tindakan dan kelompok kontrol didapatkan nilai p 0.000 . Hasil ini menunjukkan bahwa adanya perbedaan pengaruh pemberian minuman jahe hangat terhadap emesis gravidarum pada kelompok intervensi dan kelompok kontrol ibu hamil trimester I di Puskesmas Nalumsari Jepara.

\section{PEMBAHASAN \\ Frekuensi Emesis Gravidarum Kelompok Sebelum dan Sesudah Pemberian Minuman Jahe Hangat (Intervensi)}

Hasil penelitian menunjukkan adanya perbedaan rata-rata antara sebelum dan sesudah diberikan minuman jahe. Hal ini sebagaimana penelitian sebelumnya yang mendapatkan adanya pengaruh minuman jahe terhadap frekuensi mual muntah pada emesis gravidarum. Munculnya mual dan muntah pada ibu hamil karena adanya perbubahan hormonal. Dalam hal ini hormon somatomammotropin, estrogen, dan progesterone mempunyai peranan penting terhadap beberapa perubahan yang terjadi pada ibu hamil. Perubahan karena hormon estrogen pada kehamilan akan mengakibatkan pengeluaran asam lambung yang berlebihan sehingga menimbulkan rasa mual dan muntah. Selain hormon estrogen diduga pengeluaran Human Chorionic Gonadotropine (HCG) dalam serum dari plasenta juga menyebabkan mual muntah.

Faktor predisposisi yang menyebabkan mual dan muntah adalah gravid dan usia. Emesis gravidarum terjadi pada 60-80\% primigravida dan 40-60\% pada multigravida. Pada sebagian besar ibu primigravida belum beradaptasi terhadap peningkatan hormon estrogen dan HCG sehingga lebih sering mengalami emesis gravidarum (Safari, 2017). Rasa mual pada awal kehamilan dapat dikurangi dengan menggunakan terapi komplementer antara lain dengan tanaman herbal atau tradisional yang bisa dilakukan dan mudah didapatkan yaitu dengan pemberian jahe (Defrin, 2018).

Fungsi farmakologis jahe salah satunya adalah antiemetik (anti muntah). Jahe merupakan bahan yang mampu mengeluarkan gas dari dalam perut, hal ini kan meredakan perut kembung. Jahe juga merupakan stimulan aromatic yang kuat, disamping dapat 
mengendalikan muntah dengan meningkatkan gerakan peristaltic usus. Sekitar 6 senyawa di dalam jahe telah terbukti memiliki aktivitas antiemetic (anti muntah) yang manjur. Kerja senyawa tersebut lebih mengarah pada dinding lambung dari pada sistem saraf pusat (Rahmi, 2013). Pemberian minuman jahe sangat efektif dalam mengatasi mual muntah ibu hamil trimester pertama setelah pemberian intervensi minuman jahe pada kelompok intervensi dan pada kelompok eksperimen terdapat penurunan mual muntah dan banyak dialami oleh ibu yang multigravida (Ummi, 2014). Upaya pencegahan dengan memberikan minuman jahe dapat mengurangi mual dan muntah. Jahe mengandung 19 komponen yang berguna bagi tubuh yang salah satunya gingerol yaitu senyawa paling utama dan telah terbukti memiliki aktivitas antiemetik (antimuntah) yang manjur dengan bersifat memblok serotonin, yaitu senyawa kimia pembawa pesan. Senyawa ini menyebabkan perut berkontraksi yang apabila diblok maka otot-otot saluran pencernaan akan mengendor dan melemah sehingga rasa mual banyak berkurang. Dalam pencernaan jahe bersifat karminatif, yakni bahan yang mampu mengeluarkan gas dari dalam perut, hal ini akan meredakan perut kembung (Choiriyah, 2013).

Jahe juga merupakan stimulant aromatic yang kuat, disamping dapat mengendalikan muntah dengan meningkatkan gerakan peristaltik usus jahe juga mempunyai semua efek mengeluarkan. Penurunan emesis gravidarum dengan kombinasi piridosin dan jahe ekstrak menunjukkan bahwa kombinasi ekstrak jahe dan piridoksin lebih baik dibandingkan piridoksin saja dalam mengurangi mual muntah ibu hamil di bawah 3 bulan. Konsumsi ekstrak jahe sebesar 700 mg perhari sudah cukup baik untuk mengurangi keluhan mual muntah pada ibu hamil.

\section{Frekuensi Emesis Gravidarum Kelompok Sebelum dan Sesudah Pemberian Inhalasi Lemon (kontrol)}

Hasil penelitian mendapatkan frekuensi mual muntah pada kelompok kontrol sebelum tindakan rata-rata adalah 13.9 dan setelah tindakan rata-rata adalah 12.8. Hal ini menunjukkan adanya pengaruh pemberian lemon (inhalasi) terhadap penurunan mual muntah. Hal ini sesuai dengan penelitian sebelumnya yaitu frekuensi mual muntah sebelum diberikan inhalasi aromaterapi lemon diperoleh nilai rata-rata 24.67 dan frekuensi mual muntah sesudah diberikan inhalasi aromaterapi lemon diperoleh rata-rata 17.87 Ada pengaruh pemberian inhalasi aromaterapi lemon terhadap morning sickness pada ibu hamil. Penggunaan lemon sebagai bahan herbal dalam kehamilan masih sering dipakai dan dianggap sebagai obat yang aman dan efisien pada kehamilan. Ibu hamil sebanyak $40 \%$ menggunakan aroma lemon untuk meredakan rasa mual dan muntah selama hamil, dan $26,5 \%$ dari mereka telah dilaporkan sebagai cara yang efektif untuk mengontrol gejala mual muntah (Kia, 2014).

Penelitian lain juga mendapatkan bahwa lemon mampu menurunkan mual dan muntah pada ibu hamil. Lemon mengandung limonen, citral, linalyl, linalool, terpineol yang dapat menstabilkan sistem syaraf pusat, menimbulkan perasaan senang, meningkatkan nafsu makan, melancarkan peredaran darah, dan sebagai penenang (sedatif) (Kia, 2014). Memberian minyak esensial yang di hirup, maka molekul yang mudah menguap akan membawa unsur aromatik yang terdapat dalam kandungan minyak tersebut ke puncak hidung (Maternity, 2017). Rambut getar terdapat di dalamnya, yang berfungsi sebagai reseptor, akan menghantarkan pesan elektrokimia ke susunan saraf pusat. Pesan ini akan mengaktifkan pusat emosi dan daya ingat seseorang yang selanjutnya akan mengantarkan pesan balik keseluruh tubuh melalui sistem sirkulasi. Pesan yang diantar ke seluruh tubuh akan dikonversikan menjadi satu aksi dengan pelepasan substansi neuro kimia berupa perasaan senang, rileks, tenang, atau terangsang. 


\section{Pengaruh Pemberian Minuman Jahe Hangat terhadap Emesis Gravidarum}

Hasil penelitian adalah adanya pengaruh pemberian minuman jahe hangat dalam mengurangi emesis gravidarum pada kelompok intervensi dan kelompok kontrol ibu hamil trimester I di Puskesmas Nalumsari Jepara. Penelitian ini menunjukkan bahwa pemberian jahe lebih efektif dibandingkan dengan pemberian inhalasi lemon. Hal ini disebabkan jahe memberikan zat aktif lebih banyak dibandingkan dengan lemon. Jahe bermanfaat secara langsung melalui minuman yang menekan respon muntah serta aroma jahe juga bermanfaat dalam mencegah mual muntah pada ibu hamil.

Pada penelitian lain tentang pengaruh pemberian minuman jahe terhadap keluhan mual muntah pada ibu hamil trimester Satu juga menunjukkan hasil penelitian dari 15 responden sebagian besar 10 responden mengalami mual muntah $\geq 4$ kali dalam sehari sebelum diberikan minuman jahe dan setelah diberikan minuman jahe yang mengalami mual muntah $\geq 4$ kali dalam sehari sebanyak 2 responden yang mengalami mual muntah. Sedangkan dari 15 responden terdapat 5 responden mengalami mual muntah $<4$ kali dalam sehari sebelum diberikan minuman jahe dan setelah diberikan minuman jahe yang mengalami mual muntah $<4$ kali dalam sehari sebanyak 13 responden yang mengalami mual muntah. Pemberian intervensi pada kelompok yang diberikan tablet jahe pada umumnya mengalami penurunan mual muntah dibandingkan kelompok yang diberikan tablet placebo (Saswita, 2013).

Hasil penelitian ini juga sejalan dengan penelitian yang memaparkan bahwa pemberian terapi minuman jahe menunjukan penurunan morning sickness pada ibu hamil trimester I, sesudah diberikan terapi minuman jahe (Saswita, 2013). Penelitian lain yang membandingkan antara rebusan jahe dengan daun mint, diperoleh hasil bahwa pada kelompok jahe diperoleh selisih 9,87 sedangkan daun mint 6,66, sehingga dapat disimpulkan bahwa pemberian rebusan jahe lebih efektif dibanding daun mint (Parwitasari,
2014). Perbedaan jahe dengan jenis tindakan lain karena jahe yang masuk ke dalam sistem pencernaan dapat menekan mual muntah secara hormonal dan secara fisik pada gastrointestinal track, selain itu aroma jahe juga bermanfaat sebagai aroma terapi dalam mencegah mual muntah pada ibu hamil.

\section{KESIMPULAN DAN SARAN}

Ada pengaruh pemberian minuman jahe hangat terhadap emesis gravidarum pada kelompok intervensi dan kelompok kontrol pada ibu hamil trimester I di Puskesmas Nalumsari Jepara.

Ibu hamil dapat mengaplikasikan penggunaan minuman jahe hangat untuk mencegah mual muntah selama masa kehamilan.

\section{REFERENSI}

Ardani, Ayu. (2012). Perbandingan Efektifitas Pemberian Terapi Minuman Jahe dengan Minuman Kapulaga Terhadap Morning Sickness pada Ibu Hamil Trimester I di Keluarahan Ngempon Kecamatan Bergas Kabupaten Semarang. Semarang: STIKES Ngudi Waluyo Ungaran.

Choiriyah, Trisnasari. (2013). Efektivitas Konsumsi Ekstrak Jahe Dengan Frekuensi Mual Muntah Pada Ibu Hamil Di Wilayah Kerja Puskesmas Ungaran Tahun 2013.

Defrin, Dini. (2018). Pengaruh Minuman Jahe Terhadap Frekuensi Emesis Pada Ibu Hamil Trimester Pertama Di Puskesmas Pekkabata Kec. Polewali Kab. Polewali Mandar.

Kemenkes. (2013). Hasil Riset Kesehatan Dasar (RISKESDAS) Tahun 2013. http://www.kemkes.go.id

Kemenkes RI. (2017). Profil Kesehatan Indonesia Tahun 2016. http://www.depkes.go.id.index.

Khasanah, Mufidatul. (2017). Penerapan Pemberian Wedang Jahe Sunti Untuk Mengurangi Emesis Gravidarum Pada Ibu Hamil Trimester 1 Di Puskesmas 
Kebumen

3.

http://elib.stikesmuhgombong.ac.id/.pdf

Kia, Parisa Yavari et al. (2014). The Effect Of Lemon Inhalation On Nusea And Vomiting Of Pregnancy : A DoubleBlinded, Randomized,Controlled Clinical Trial. Iran Red Crescent Med J. DOI: $10.5812 /$ ircmj.14360.

Manuaba. (2012). Memahami Kesehatan Reproduksi Wanita. Ed 2. Jakarta : EGC.

Maternity, Dainty. (2017). Inhalasi Lemon Mengurangi Mual Muntah Pada Ibu Hamil Trimester Satu. https://www. ejournal.Ippmstikesjayc.ac.id

Mochtar, Rustam. (2013). Sinopsis Obstery; obstetric fisiologi dan patologi. EGC, Jakarta.

Parwitasari, Chatur. (2015). Perbandingan Efektivitas Pemberian Rebusan Jahe Dan Daun Mint Terhadap Mual Muntah Pada Ibu Hamil.

Putri, Ayu. (2017). Efektifitas Pemberian Jahe Hangat Dalam Mengurangi Frekuensi Mual Muntah Pada Ibu Hamil Trimester I. http://eprints.uad.ac.id/

Rahmi. (2013). Efektivitas Jahe Untuk Menurunkan Mual Muntah Pada Kehamilan Trimester Pertama Di Puskesmas Dolok Masihul kec. Dolok
Masihul Kab. Serdang Bedagai. Jurnal Maternity and Neonatal, Vol 1 No.2.

Rofi'ah Siti. (2017). Efektivitas Konsumsi Jahe Dan Sereh Dalam Mengatasi Morning Sickness.

http://journal.unair.ac.id/downloadfull

Saberi, et all. (2014). Effect of Ginger on Relieving Nausea and Vomiting in Pregnancy. Iran Red Crescent Med

Safari, Fifi. (2017). Hubungan Karakteristik Dan Psikologis Ibu Hamil Dengan Hiperemesis Gravidarum Di RSUD $\mathrm{H}$. Abd. Manan Simatupang Kisaran. http://penelitian.uisu.ac.id/wpcontent/uploads/2017/.pdf

Saswita. (2013). Efektifitas Jahe Dalam Mengurangi Emesis Gravidarum pada Ibu Hamil Trimester I. 1, Jurnal Ners Indonesia, Vol. 2.

Syaifudin dkk, (2010). Buku Acuan Nasional Pelayanan Kesehatan Maternal dan Neonatal. Ed. 1, Cet. 4-. YBPSP, Jakarta.

Ummi, HA. (2014). Efektivitas Pemberian Wedang Jahe (Zingiber Officinale Var. Rubrum) Terhadap Penurunan Emesis Gravidarum Pada Trimester Pertama, Jurnal Biometrika dan Kependudukan, Vol 3 No.1 Juli 2014 81-87. 